\title{
GMR
}

\section{Genetic progress in sunflower crop in Rio Grande do Sul State, Brazil}

\author{
D.N. Follmann', A. Cargnelutti Filho', L.H. Lorentz ${ }^{2}$, A.A. Boligon ${ }^{2}$, \\ M. Caraffa ${ }^{3}$ and C.A. Wartha ${ }^{1}$ \\ ${ }^{1}$ Departamento de Fitotecnia, Universidade Federal de Santa Maria, \\ Santa Maria, RS, Brasil \\ ${ }^{2}$ Universidade Federal do Pampa, São Gabriel, RS, Brasil \\ ${ }^{3}$ Departamento de Agronomia, Sociedade Educacional Três de Maio, \\ Três de Maio, RS, Brasil \\ Corresponding author: A. Cargnelutti Filho \\ E-mail: alberto.cargnelutti.filho@gmail.com \\ Genet. Mol. Res. 16 (2): gmr16029520 \\ Received November 7, 2016 \\ Accepted February 16, 2017 \\ Published April 13, 2017 \\ DOI http://dx.doi.org/10.4238/gmr16029520 \\ Copyright $(2017$ The Authors. This is an open-access article distributed under the terms of \\ the Creative Commons Attribution ShareAlike (CC BY-SA) 4.0 License.
}

\begin{abstract}
The sunflower has adaptability to growing regions with different climatic and soil characteristics, showing drought tolerance and high-quality oil production. The State of Rio Grande do Sul is the third largest sunflower producer in Brazil, with research related to the sunflower breeding initiated after the decade of 1950. The aim of this study was to evaluate the genetic progress for grain yield, oil content, and oil yield of sunflower (Helianthus annuus L.) in the State of Rio Grande do Sul. Data of grain yield, oil content, and oil yield obtained from 58 sunflower cultivar yield trials in 19 municipalities in Rio Grande do Sul during the period from 2005 to 2014 were used. Genetic progress was studied according to the methodology proposed by Vencovsky and data from sunflower cultivar yield trials were used. Annual genetic progress of sunflower during the period of 10 years (2005-2014) was $132.46 \mathrm{~kg} \cdot \mathrm{ha}^{-1} \cdot$ year $^{-1}$ for grain yield, $-0.17 \% /$ year for oil content, and $48.11 \mathrm{~kg} \cdot \mathrm{ha}^{-1} \cdot \mathrm{year}^{-1}$ for oil yield. The sunflowerbreeding programs in the State of Rio Grande do Sul were efficient for
\end{abstract}

Genetics and Molecular Research 16 (2): gmr16029520 
the traits grain yield and oil yield and presented no efficiency for oil content.

Key words: Helianthus annuus L.; Genetic breeding; Grain yield; Oil content; Oil yield

\section{INTRODUCTION}

The sunflower is an oleaginous plant with great importance worldwide, producing oil with excellent quality. Sunflower genetic breeding in Brazil has initial records in 1932 in São Paulo and from the decade of 1950 in Rio Grande do Sul. Among the highlighted characteristics, it has wide adaptability, drought tolerance, and excellent expansion perspectives in Brazil, arousing the interest of public and private companies in the development of breeding programs with the crop (Castiglioni and Oliveira, 2005).

Sunflower cultivation concentrates mostly in the Central-Southern region of Brazil. The Brazilian production in the 2012/2013 agricultural year was 108,100 ton in 68,700 hectares of growing area. The State of Rio Grande do Sul is the third largest producer in Brazil, with production of 4000 ton in 2700 hectares of growing area (CONAB, 2013).

The main sunflower product commercialized is its oil intended for human consumption and used as biofuel. Studies and selections to increase the oil content of sunflower achenes were initially developed in Russia, where Pustovoit developed an efficient method for genotype selection in breeding programs. It allowed the selection of genotypes with oil content higher than $50 \%$ and the method became known worldwide as the method of reserves (Castiglioni and Oliveira, 2005).

Current studies that assess the performance of sunflower cultivars prioritize oil yield in addition to grain yield (Porto et al., 2008; Thomaz et al., 2012, Schwerz et al., 2015; Dalchiavon et al., 2016) and oil content (Schwerz et al., 2015; Dalchiavon et al., 2016). It demonstrates the interest in genotypes with high grain yield and oil yield associated with a high oil content, which provides better industrial performance for its extraction.

The efficiency of plant-breeding programs in providing genotypes with greater yield potential can be assessed by studying the genetic progress (Borges et al., 2009). Among the possibilities of evaluating the genetic progress, the method developed by Vencovsky et al. (1988) presents an advantage of using trials that have been performed on cultivar yield trial networks, besides the advantage of measuring genotypes in the closest possible growing conditions performed by farmers due to carrying out trials on a large number of locations. Another advantage that can be attributed to this methodology is the cost reduction (Faria et al., 2007) because the installation of a particular experiment is not necessary to perform the study (Toledo et al., 1990).

Studies regarding the breeding program efficiency with sunflower can be found in Argentina, indicating genetic progress of grain yield (Pereira et al., 1999), grain yield, oil content, and oil yield (de la Vega et al., 2007), and oil yield (de la Vega, 2012). Also in South Africa, studies of grain yield, oil content, and oil yield (Chigeza et al., 2012). It is assumed that for the State of Rio Grande do Sul, there was genetic progress for sunflower grain yield, oil content, and oil yield during the period of 2005 to 2014.

Thus, the aim of this study was to evaluate the genetic progress for grain yield, oil content, and oil yield of sunflower (Helianthus annuus L.) in the State of Rio Grande do Sul.

Genetics and Molecular Research 16 (2): gmr16029520 


\section{MATERIAL AND METHODS}

Data of grain yield (GY, in $\mathrm{kg} / \mathrm{ha}$ ), oil content (OC, in \%), and oil yield (OY, in $\mathrm{kg} / \mathrm{ha}$ ) of 58 trials belonging to the sunflower $(H$. annuus L.) genotype yield trial network were used. Trials were performed in 19 municipalities of Rio Grande do Sul during the period of 2005 to 2014 (Figure 1). Data were obtained from the Reports of the sunflower genotype assessments published annually by the Brazilian Agricultural Research Corporation (EMBRAPA) (Table 1).

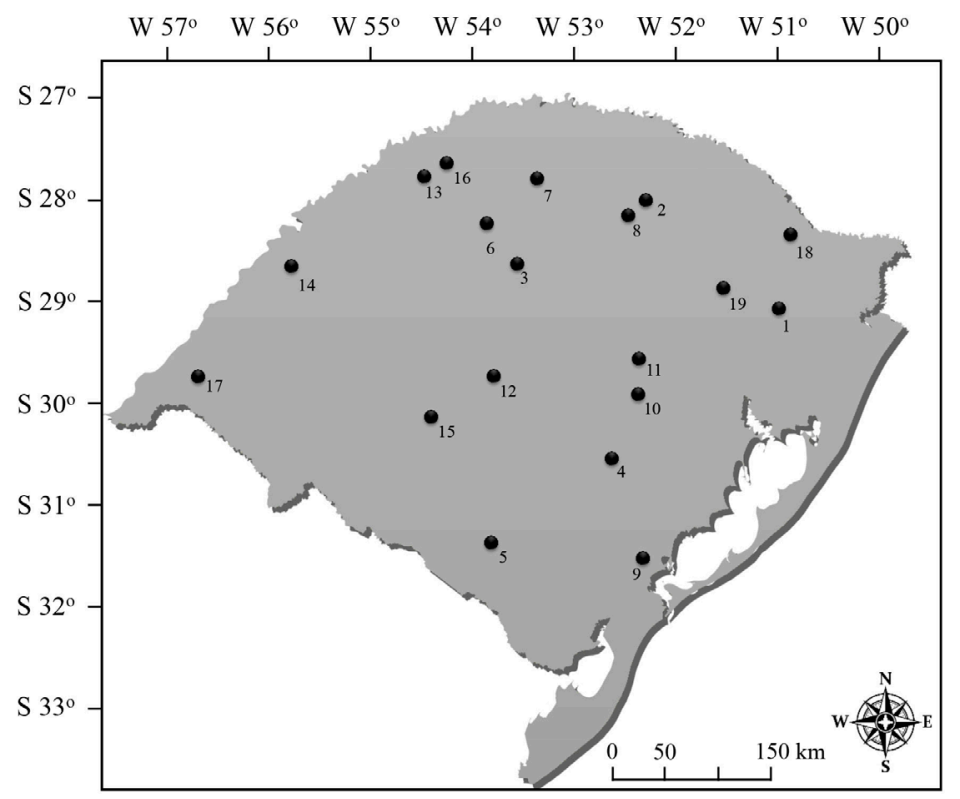

Figure 1. Geographical representation of the 19 locations of cultivar trials of the Official Sunflower Yield Trial Network in Rio Grande do Sul during the period of 2005 to 2014. 1 = Caxias do Sul; 2 = Coxilha; 3 = Cruz Alta; 4 = Encruzilhada do Sul; 5 = Hulha Negra; 6 = Ijuí; 7 = Palmeira das Missões; $8=$ Passo Fundo; $9=$ Pelotas; 10 = Rio Pardo; $11=$ Santa Cruz do Sul; 12 = Santa Maria; $13=$ Santa Rosa; 14 = São Borja; 15 = São Gabriel; $16=$ Três de Maio; 17 = Uruguaiana; 18 = Vacaria; 19 = Veranópolis.

Table 1. List of documents published annually by the Brazilian Agricultural Research Corporation (EMBRAPA) in partnership with public and private institutions regarding the sunflower (Helianthus annuus L.) cultivar yield trial network during the period of 2005 to 2014 in the State of Rio Grande do Sul, Brazil.

\begin{tabular}{|c|c|c|c|c|}
\hline Year & Document & Authors & \begin{tabular}{|l|l} 
Initial and final pages \\
\end{tabular} & Number of trials \\
\hline $2005 / 2006$ and 2006 & Document 285 - Reports of the sunflower genotype assessment, 2007. 120p. & Carvalho et al. (2007) & $20-21 ; 22-23 ; 24-25 ; 35-36 ; 37-38 ; 39-40$ & 6 \\
\hline $2006 / 2007$ and 2007 & Document 295 - Reports of the sunflower genotype assessment, 2008. 108p. & Carvalho et al. (2008) & $\begin{array}{l}21-22 ; 23-24 ; 25-26 ; 27-28 ; 36-37 ; 38-39 ; 40- \\
41 ; 42-43 ; 44-45 ; 46-47 ; 48-49\end{array}$ & 11 \\
\hline $2007 / 2$ & Document 316 - Reports of the sunflower ger & Car & $19-20 ; 20-21 ; 33-34 ; 35-36$ & 4 \\
\hline $2008 / 2009$ and 2009 & Document 320 - Reports of the sunflower genotype assessment, 2009. 122p. & Carvalho et al. (2009b) & \begin{tabular}{|l|}
$22-23 ; 24-25 ; 26-27 ; 47-48 ; 49-50 ; 51-52 ; 53-$ \\
$54 ; 56-58$
\end{tabular} & 8 \\
\hline $2009 / 2010$ and 2010 & Document 326 - Reports of the sunflower genotype assessment, 2011. 108p. & Carvalho et al. (2011a) & $\begin{array}{l}21-22 ; 23-24 ; 25-26 ; 27-28 ; 42-43 ; 44-45 ; 46- \\
47 ; 48-49\end{array}$ & 8 \\
\hline $2010 / 2011$ and 2011 & Document 329 - Reports of the sunflower & Carv & $21-22 ; 23-24 ; 35-36 ; 37-38 ; 39-40$ & 5 \\
\hline $2011 / 2012$ and 2012 & Document 340 - Reports of the sunflower genotype assessment, 2013. 104p. & Carvalho et al. (2013) & $\begin{array}{l}22-23 ; 24-25 ; 26-27 ; 28-29 ; 39-40 ; 41-42 ; 43- \\
44 ; 45-46\end{array}$ & 8 \\
\hline $2012 / 2$ & Document 355 - Reports o & et al. (2014) & $22-23 ; 39-40 ; 41-42 ; 43-44$ & 4 \\
\hline $2013 / 2$ & Document 3 & a) & $24-25 ; 42-43$ & \\
\hline $2014 / 2015$ and 2015 & Document 367 - Reports o & Carvalho et al. (2015b) & $24-25 ; 38-39$ & 2 \\
\hline
\end{tabular}

All trials were carried out using the randomized block design arranged with four replications. The experimental units consisted of four rows with $6 \mathrm{~m}$ long and spacing $0.80 \mathrm{~m}$. Plot area was $19.2 \mathrm{~m}^{2}$ with useful area of $8.0 \mathrm{~m}^{2}$.

Genetics and Molecular Research 16 (2): gmr16029520 
The calculation of genetic progress was performed for the State of Rio Grande do Sul with the results obtained from cultivar trials performed in the municipalities of Caxias do Sul, Coxilha, Cruz Alta, Encruzilhada do Sul, Hulha Negra, Ijuí, Palmeira das Missões, Passo Fundo, Pelotas, Rio Pardo, Santa Cruz do Sul, Santa Maria, Santa Rosa, São Borja, São Gabriel, Três de Maio, Uruguaiana, Vacaria, and Veranópolis (Table 2).

Table 2. Number of trials in each location and year and totals per trial and per year, carried out in the network of sunflower (Helianthus annuus L.) cultivar trials from 2005 to 2014 in Rio Grande do Sul, Brazil and total number of sunflower cultivars assessed in each year.

\begin{tabular}{|c|c|c|c|c|c|c|c|c|c|c|c|}
\hline \multirow[t]{2}{*}{ Locations } & \multicolumn{10}{|c|}{ Years } & \multirow[t]{2}{*}{ Total } \\
\hline & 2005 & 2006 & 2007 & 2008 & 2009 & 2010 & 2011 & 2012 & 2013 & 2014 & \\
\hline Caxias do Sul & - & - & - & - & - & - & 1 & - & - & - & 1 \\
\hline Coxilha & - & - & - & - & - & 1 & - & - & - & - & 1 \\
\hline Cruz Alta & 1 & - & - & - & - & - & - & - & - & - & 1 \\
\hline Encruzilhada do Sul & - & 1 & 1 & - & 1 & - & 1 & - & - & - & 4 \\
\hline Hulha Negra & - & - & - & - & - & - & 1 & - & - & - & 1 \\
\hline Ijuí & 2 & - & - & 1 & - & - & - & - & - & - & 3 \\
\hline Palmeira das Missões & - & 1 & - & - & - & - & - & - & - & - & 1 \\
\hline Passo Fundo & 2 & 2 & - & 1 & 1 & - & 1 & 1 & 1 & 1 & 10 \\
\hline Pelotas & - & - & - & - & - & 1 & - & - & - & - & 1 \\
\hline Rio Pardo & - & - & - & 1 & - & 1 & 1 & 1 & - & - & 4 \\
\hline Santa Cruz do Sul & - & 1 & 1 & - & - & - & - & - & - & - & 2 \\
\hline Santa Maria & - & 1 & - & - & - & - & - & - & - & - & 1 \\
\hline Santa Rosa & - & 1 & - & 1 & 1 & - & - & - & - & - & 3 \\
\hline São Borja & - & 1 & - & 1 & 1 & - & - & 1 & - & - & 4 \\
\hline São Gabriel & - & 1 & 1 & - & - & - & 1 & - & - & - & 3 \\
\hline Três de Maio & 1 & - & 1 & 1 & 1 & 1 & - & 1 & 1 & 1 & 8 \\
\hline Uruguaiana & - & - & - & - & 1 & - & - & - & - & - & 1 \\
\hline Vacaria & - & 1 & - & 1 & 1 & 1 & 1 & - & - & - & 5 \\
\hline Veranópolis & - & 1 & - & 1 & 1 & - & 1 & - & - & - & 4 \\
\hline Total of trials & 6 & 11 & 4 & 8 & 8 & 5 & 8 & 4 & 2 & 2 & 58 \\
\hline Total of cultivars in each year & 26 & 40 & 42 & 34 & 31 & 28 & 25 & 28 & 28 & 17 & 173 \\
\hline
\end{tabular}

(-) Absence of trial.

Trials were designed to generate information for recommendation of cultivars with better performance on exposure to different growing environments. Cultivars with unsatisfactory performance were discarded and replaced by others, supposedly with greater yield potential. Cultivars that exhibited proper performance were maintained for evaluation in the following year.

The methodology proposed by Vencovsky et al. (1988) was used in order to study the genetic progress. This methodology is based on the data generated in the regional cultivar trials. Moreover, it is intended to obtain genetic gain estimates, being the genetic progress balance performed by the method of generalized least squares (Cruz, 2001).

Thus, initially rates of included (I), deleted (D), maintained (M), and renewed (R) cultivars in the trials were estimated in $\%$ by the following formulas:

$$
\begin{aligned}
& \% I=\frac{100 I}{M+D+I} \\
& \% D=\frac{100 D}{M+D+I}
\end{aligned}
$$

Genetics and Molecular Research 16 (2): gmr16029520 


$$
\begin{gathered}
\% M=\frac{100 M}{M+D+I} \\
\% R=\frac{100 I}{M+I}
\end{gathered}
$$

where I = number of cultivars included in the following year; $\mathrm{D}=$ number of cultivars deleted in the previous year; $\mathrm{M}=$ number of cultivars maintained from one year to another; and $\mathrm{R}=$ renewal of cultivars (Cruz, 2001).

Following, genetic gain was estimated in every 2 years, with the linear regression model proposed by Vencovsky et al. (1988), consisting of:

$$
\hat{G} g=(\bar{y} 2-\bar{y} 1)-(\bar{y} c 2-\bar{y} c 1) \quad \text { (Equation 5) }
$$

where $\hat{G} g=$ Estimate of genetic gain; $\bar{y} 1=$ Overall mean of cultivars in the trial of year $1 ; \bar{y} 2=$ Overall mean of cultivars in the trial of year $2 ; \overline{\mathrm{y}} \mathrm{c}=$ Overall mean of common cultivars in the trial of year $1 ; \bar{y} c 2=$ Overall mean of common cultivars in the trial of year 2.

In this methodology, the gross difference is obtained by $(\bar{y} 2-\bar{y} 1)$ and the environmental difference is obtained by $(\bar{y} c 2-\bar{y} c 1)$. Thus, the genetic gain estimate is obtained by the gross difference minus the environmental difference (Vencovsky et al., 1988).

Subsequently, the genetic progress balance was determined by the method of generalized least squares, as described in Cruz (2001). Genetic gain mean of the period $\left(\mu \hat{G} g\right.$ ) (was obtained in $\mathrm{kg} \mathrm{ha}^{-1}$ year ${ }^{-1}$ for GY and OY, and in \%/year for OC. Then, the percentage of annual genetic progress was calculated by the formula:

$$
\frac{\mu \hat{G} g}{\bar{y} 1} * 100
$$

For statistical analysis, the Microsoft Office Excel application and Genes software (Cruz, 2013) were used.

\section{RESULTS AND DISCUSSION}

Of the 58 sunflower cultivar assessment trials carried out during the period of 10 years (2005-2014) in the State of Rio Grande do Sul, 173 genotypes were assessed (Table 2). The year with the highest number of assessed genotypes was 2007 with 42 genotypes and the year of 2014 was the year with lower number of genotypes, presenting 17 genotypes.

Means of inclusion (33.4\%), deletion (37.33\%), and maintenance $(29.23 \%)$ rates of cultivars during the period from 2005 to 2014 were relatively lower than the renewal rate $(52.79 \%)$ (Table 3$)$. The renewal rate of cultivars was high compared to the values found in genetic progress studies in wheat with 33\% (Cargnin et al., 2008) and 29\% with rice (DoVale et al., 2012). These results demonstrate that the sunflower-breeding program is dynamic, with constant investments in research for the release of new cultivars.

Genetics and Molecular Research 16 (2): gmr16029520 
Table 3. Rates of inclusion, deletion, maintenance, and renewal of cultivars assessed in the sunflower cultivar trial network during the period of 2005 to 2014 in Rio Grande do Sul, Brazil.

\begin{tabular}{l|c|c|c|c}
\hline Bienniums & Inclusion (\%) & Deletion (\%) & Maintenance (\%) & Renewal (\%) \\
\hline $2006-2005$ & 55.17 & 31.03 & 13.79 & 80.00 \\
\hline $2007-2006$ & 36.51 & 33.33 & 30.16 & 54.76 \\
\hline $2008-2007$ & 33.33 & 46.03 & 20.63 & 61.76 \\
\hline $2009-2008$ & 34.62 & 40.38 & 25.00 & 58.06 \\
\hline $2010-2009$ & 31.11 & 37.78 & 31.11 & 50.00 \\
\hline $2011-2010$ & 30.00 & 37.50 & 32.50 & 48.00 \\
\hline $2012-2011$ & 41.86 & 34.88 & 23.26 & 64.29 \\
\hline $2013-2012$ & 31.71 & 31.71 & 36.59 & 46.43 \\
\hline Mean of nine bienniums & 6.67 & 43.33 & 50.00 & 11.76 \\
\hline
\end{tabular}

Considering all locations and years, the overall mean for GY was $2075.57 \mathrm{~kg} / \mathrm{ha}$, $43.24 \%$ for OC and $897.71 \mathrm{~kg} / \mathrm{ha}$ for OY (Table 4). The year with the lowest GY mean was 2005 with $1543.65 \mathrm{~kg} / \mathrm{ha}$. Meanwhile, the year with greater GY was 2010 with $2775.86 \mathrm{~kg} /$ ha. These values demonstrate crop yield increase in the State of Rio Grande do Sul, possibly by the release of new cultivars and improvements related to crop management. Globally, the expansion and establishment of sunflower occurred with the introduction of new cultivars, where they contributed with the increase of $60 \%$ in GY (Castiglioni and Oliveira, 2005).

Table 4. Means of grain yield, oil content, and oil yield of cultivars assessed in the sunflower (Helianthus annuиs L.) cultivar trial network during the period of 2005 to 2014 in the State of Rio Grande do Sul, Brazil.

\begin{tabular}{l|c|c|c}
\hline Year & Grain yield (kg/ha) & Oil content (\%) & Oil yield (kg/ha) \\
\hline 2005 & 1543.65 & 43.83 & 674.66 \\
\hline 2006 & 2113.69 & 43.76 & 921.92 \\
\hline 2007 & 2136.74 & 41.85 & 897.24 \\
\hline 2008 & 1723.66 & 43.62 & 750.16 \\
\hline 2009 & 1765.48 & 43.79 & 772.55 \\
\hline 2010 & 2775.86 & 42.46 & 1185.99 \\
\hline 2011 & 2150.70 & 43.84 & 948.10 \\
\hline 2012 & 1874.12 & 42.25 & 792.20 \\
\hline 2013 & 2358.88 & 42.68 & 1007.76 \\
\hline 2014 & 2312.88 & 44.31 & 1026.49 \\
\hline Mean of the period & 2075.57 & 43.24 & 897.71 \\
\hline
\end{tabular}

The genetic progress of sunflower cultivars in the State of Rio Grande do Sul during the period from 2005 to 2014 was $132.46 \mathrm{~kg} \cdot \mathrm{ha}^{-1} \cdot$ year $^{-1}$ ( $8.58 \%$ per year) for GY, $-0.17 \%$ /year $\left(-0.38 \%\right.$ per year) for OC, and $48.11 \mathrm{~kg} \cdot \mathrm{ha}^{-1} \cdot \mathrm{year}^{-1}(7.13 \%$ per year) for OY (Table 5$)$. Thus, it can be inferred that the breeding programs were efficient in releasing cultivars for GY and OY traits and the breeding programs demonstrated no efficiency for the $\mathrm{OC}$ trait.

Studies on the genetic progress for GY with sunflower were reported in Argentina, with genetic progress of $49 \mathrm{~kg} \mathrm{ha}^{-1}$ year-1 (Pereira et al., 1999), $11.9 \mathrm{~kg} \cdot \mathrm{ha}^{-1} \cdot \mathrm{year}^{-1}$ (de la Vega et al., 2007), and in South Africa with $24 \mathrm{~kg} \cdot \mathrm{ha}^{-1} \cdot$ year $^{-1}$ (Chigeza et al., 2012). Genetic progress for OC of $0.19 \% / y e a r$ (de la Vega et al., 2007) and $0.12 \%$ year (Chigeza et al., 2012) was also found. Genetic progress for OY of $16.1 \mathrm{~kg} \cdot \mathrm{ha}^{-1} \cdot \mathrm{year}^{-1}$ (de la Vega et al., 2007), of $12 \mathrm{~kg} \cdot \mathrm{ha}$ ${ }^{1}$.year ${ }^{-1}$ (Chigeza et al., 2012), and of 6.22 to $10.54 \mathrm{~kg} \cdot \mathrm{ha}^{-1} \cdot \mathrm{year}^{-1}$ (de la Vega, 2012) was found by growing regions.

The genetic progress of sunflower for the State of Rio Grande do Sul was greater for GY than the studies found in the literature (Pereira et al., 1999; de la Vega et al., 2007; Chigeza et al., 2012). Moreover, it was also greater for OY than other studies (de la Vega et al.,

Genetics and Molecular Research 16 (2): gmr16029520 
Table 5. Annual genetic progress and percentage of annual genetic progress for grain yield, oil content, and oil yield of sunflower cultivars (Helianthus annuus L.) of the State of Rio Grande do Sul during the period of 2005 to 2014.

\begin{tabular}{l|c|c|c}
\hline & Grain yield (kg/ha) & Oil content (\%) & Oil yield (kg/ha) \\
\hline & \multicolumn{3}{|c|}{ Annual genetic progress } \\
\hline $2006-2005$ & -156.19 & -1.09 & -98.12 \\
\hline $2007-2006$ & 658.50 & -0.40 & 261.86 \\
\hline $2008-2007$ & 385.60 & 0.92 & 163.76 \\
\hline $2009-2008$ & 74.11 & 0.08 & 33.11 \\
\hline $2010-2009$ & 168.24 & 1.12 & 116.83 \\
\hline $2011-2010$ & 157.75 & 1.61 & 105.41 \\
\hline $2012-2011$ & -74.33 & -1.43 & -57.81 \\
\hline $2013-2012$ & -304.64 & -0.59 & -144.25 \\
\hline $2014-2013$ & -225.76 & -0.48 & -104.19 \\
\hline & & \multicolumn{3}{|c}{ Balance of the annual genetic progress } \\
\hline Genetic gain per year & 132.46 & -0.17 & 48.11 \\
\hline Genetic gain in \%/year & 8.58 & -0.38 & 7.13 \\
\hline
\end{tabular}

2007; Chigeza et al., 2012; de la Vega, 2012). However, genetic progress for OC was below those found in other countries (de la Vega et al., 2007; Chigeza et al., 2012). One explanation for this can be the elevated OC levels present in Brazilian genotypes (mean of $43.24 \%$ in studies performed from 2005 to 2014 in Rio Grande do Sul), hindering selection for release of cultivars with higher oil levels.

The OY is the trait with greater economic interest in sunflower and its increase has being achieved in sunflower with increasing GY. Regarding GY in other crops, recent studies indicated genetic progress of 0.92\%/year for wheat in Brazil (Beche et al., 2014), 1\%/year for wheat in China (Wu et al., 2014), 0.67\%/year for rice in Brazil (Breseghello et al., 2011), and 1.1\%/year for soybean in Argentina (Felipe et al., 2016).

The genetic progress for sunflower was greater than in other crops, which can be justified by the sunflower allogamous reproductive system, enabling high genetic information exchange with different sources of germplasm during the initial phase of breeding, expanding its genetic basis. Furthermore, it can be used to produce open population cultivars or genetic basis for the formation of inbreed lines, which are benefiting from the hybrid vigor resulting from the heterosis present in hybrid sunflower cultivars.

\section{CONCLUSION}

Annual genetic progress of sunflower during the period of 10 years (2005-2014) was $132.46 \mathrm{~kg} \cdot \mathrm{ha}^{-1} \cdot$ year $^{-1}$ for grain yield, $-0.17 \% /$ year for oil content, and $48.11 \mathrm{~kg} \cdot \mathrm{ha}^{-1} \cdot \mathrm{year}^{-1}$ for oil yield. The sunflower-breeding programs in the State of Rio Grande do Sul were efficient for the traits grain yield and oil yield and presented no efficiency for oil content.

\section{Conflicts of interest}

The authors declare no conflict of interest.

\section{ACKNOWLEDGMENTS}

We thank the researchers from Empresa Brasileira de Pesquisa Agropecuária (EMBRAPA) and from other research institutions for performing these trials. Moreover, we appreciate Conselho Nacional de Desenvolvimento Científico e Tecnológico (CNPq) for

Genetics and Molecular Research 16 (2): gmr16029520 
the productivity research grant and Coordenação de Aperfeiçoamento de Pessoal de Nível Superior (CAPES) for granting scholarships.

\section{REFERENCES}

Beche E, Benin G, Silva CL, Munaro LB, et al. (2014). Genetic gain in yield and changes associated with physiological traits in Brazilian wheat during the 20th century. Eur. J. Agron. 61: 49-59 http://dx.doi.org/10.1016/j.eja.2014.08.005.

Borges V, Soares AA, Resende MDV, Reis MS, et al. (2009). Progresso genético do programa de melhoramento de arroz de terras altas de minas gerais utilizando modelos mistos. Rev. Bras. Biol. 27: 478-490.

Breseghello F, Morais OP, Pinheiro PV, Silva ACS, et al. (2011). Results of 25 years of upland rice breeding in Brazil. Crop Sci. 51: 914-923 http://dx.doi.org/10.2135/cropsci2010.06.0325.

Cargnin A, Souza MA and Fronza V (2008). Progress in breeding of irrigated wheat for the cerrado region of Brazil. Crop Breed. Appl. Biotechnol. 8: 39-46. http://dx.doi.org/10.12702/1984-7033.v08n01a06

Carvalho CGP, Oliveira ACB, Marques CRG, Salasar FPLT, et al. (2007). Documentos 285 - Informes da Avaliação de Genótipos de Girassol 2005/2006 e 2006. 1st edn. EMBRAPA.

Carvalho CGP, Grunvald AK, Oliveira ACB, Salasar FPLT, et al. (2008). Documentos 295 - Informes da Avaliação de Genótipos de Girassol 2006/2007 e 2007. 1st edn. EMBRAPA.

Carvalho CGP, Grunvald AK, Terra IM, Oliveira ACB, et al. (2009a). Documentos 316 - Informes da Avaliação de Genótipos de Girassol 2007/2008 e 2008. 1st edn. EMBRAPA.

Carvalho CGP, Grunvald AK, Gonçalves SL, Terra IM et al. (2009b). Documentos 320 - Informes da Avaliação de Genótipos de Girassol 2008/2009 e 2009. 1st edn. EMBRAPA.

Carvalho CGP, Gonçalves JL, Grunvald AK, Gonçalves SL et al. (2011a). Documentos 326 - Informes da Avaliação de Genótipos de Girassol 2009/2010 e 2010. 1st edn. EMBRAPA.

Carvalho CGP, Grunvald AK, Gonçalves SL, Godinho VPC, et al. (2011b). Documentos 329 - Informes da Avaliação de Genótipos de Girassol 2010/2011 e 2011. 1st edn. EMBRAPA.

Carvalho CGP, Chinaglia VG, Oliveira ACB, Godinho VPC, et al. (2013). Documentos 340 - Informes da Avaliação de Genótipos de Girassol 2011/2012 e 2012. 1st edn. EMBRAPA.

Carvalho CGP, Silva MF, Amabile RF, Godinho VPC et al. (2014). Documentos 355 - Informes da Avaliação de Genótipos de Girassol 2012/2013 e 2013. 1st edn. EMBRAPA.

Carvalho CGP, Silva MF, Godinho VPC, Amabile RF, et al. (2015a). Documentos 360 - Informes da Avaliação de Genótipos de Girassol 2013/2014 e 2014. 1st edn. EMBRAPA.

Carvalho CGP, Fujii LH, Amabile RF, Ribeiro JL, et al. (2015b). Documentos 367 - Informes da Avaliação de Genótipos de Girassol 2014/2015 e 2015. 1st edn. EMBRAPA.

Castiglioni VBR and Oliveira MF (2005). Melhoramento do Girassol. In: Melhoramento de espécies cultivadas (Borém A, ed.). 2nd edn. Editora UFV, Viçosa.

Chigeza G, Mashingaidze K and Shanahan P (2012). Seed yield and associated trait improvements in sunflower cultivars over four decades of breeding in South Africa. Field Crops Res. 130: 46-56. http://dx.doi.org/10.1016/j.fcr.2012.01.015

CONAB (2013). Acompanhamento da safra brasileira. Available at [http://www.conab.gov.br/OlalaCMS/uploads/ arquivos/13_09_10_16_05_53_boletim_portugues_setembro_2013.pdf]. Accessed August 30, 2016.

Cruz CD (2001). Programa genes: versão windows, aplicativo computacional em genética e estatística. 1st edn. Editora UFV, Viçosa.

Cruz CD (2013). Genes - a software package for analysis in experimental statistics and quantitative genetics. Acta Sci. Agron. 35: 271-276 http://dx.doi.org/10.4025/actasciagron.v35i3.21251.

Dalchiavon FC, Malacarne BJ and Carvalho CGP (2016). Características agronômicas de genótipos de girassol (Helianthus annuus L.) em segunda safra no Chapadão do Parecis - MT. Rev. Cienc. Agrar. (Belem.) 39: 178-186.

de la Vega AJ (2012). Effect of the complexity of sunflower growing regions on the genetic progress achieved by breeding programs. Helia 35: 113-122. http://dx.doi.org/10.2298/HEL1257113V

de la Vega AJ, DeLacy IH and Chapman SC (2007). Changes in agronomic traits of sunflower hybrids over 20 years of breeding in central Argentina. Field Crops Res. 100: 73-81. http://dx.doi.org/10.1016/j.fcr.2006.05.007

DoVale JC, Soares PC, Cornélio VMO, Reis MS, et al. (2012). Contribuição genética na produtividade do arroz irrigado em Minas Gerais no período de 1998 a 2010. Bragantia 71: 460-466 http://dx.doi.org/10.1590/S000687052012000400002.

Faria AP, Fonseca Júnior NS, Destro D and Faria RT (2007). Ganho genético na cultura da soja. Semin. Cienc. Agrar. 28: 71-78 http://dx.doi.org/10.5433/1679-0359.2007v28n1p71.

Genetics and Molecular Research 16 (2): gmr16029520 
Felipe M, Gerde JA and Rotundo JL (2016). Soybean genetic gain in maturity groups III to V in Argentina from 1980 to 2015. Crop Sci. 56: 1-12. http://dx.doi.org/10.2135/cropsci2016.04.0214

Pereira ML, Sadras VO and Trápani N (1999). Genetic improvement of sunflower in Argentina between 1930 and 1995. I. Yield and its components. Field Crops Res. 62: 157-166. http://dx.doi.org/10.1016/S0378-4290(99)00015-5

Porto WS, Carvalho CGP, Pinto RJB, Oliveira MF, et al. (2008). Evaluation of sunflower cultivars for central Brazil. Sci. Agric. 65: 139-144. http://dx.doi.org/10.1590/S0103-90162008000200005

Schwerz T, Jakelaitis A, Teixeira MB, Soares FAL, et al. (2015). Produção de girassol cultivado após soja, milho e capim-marandu, com e sem irrigação suplementar. Rev. Bras. Eng. Agric. Ambient. 19: 470-475. http://dx.doi. org/10.1590/1807-1929/agriambi.v19n5p470-475

Thomaz GL, Zagonel J, Colasante LO and Nogueira RR (2012). Produção do girassol e teor de óleo nos aquênios em função da temperatura do ar, precipitação pluvial e radiação solar. Cienc. Rural 42: 1380-1385. http://dx.doi. org $/ 10.1590 / \mathrm{S} 0103-84782012000800008$

Toledo JFF, Almeida LA, Kiihl RAS and Menosso OG (1990). Ganho genético em soja no estado do Paraná, via melhoramento. Pesqui. Agropecu. Bras. 25: 89-94.

Vencovsky R, Morais AR, Garcia JC and Teixeira NM (1988). Progresso genético em vinte anos de melhoramento do milho no Brasil. In: Congresso Nacional de Milho e Sorgo 16: 300-307.

Wu W, Li C, Ma B, Shah F, et al. (2014). Genetic progress in wheat yield and associated traits in China since 1945 and future prospects. Euphytica 196: 155-168 http://dx.doi.org/10.1007/s10681-013-1033-9.

Genetics and Molecular Research 16 (2): gmr16029520 